\section{Reseptorer i kompleks gir bedre funksjon}

Gjenkjennelsesreseptorene MCL og Micle danner et proteinkompleks på overflaten av myeloide celler hos rotter. Det gir bedre immunrespons enn reseptorene hver for seg.

Celler i det medfødte immunforsvaret har en type reseptorer på overflaten som kan fange opp forskjell mellom egne og fremmede strukturer. Disse reseptorene kalles Pattern Recognition Receptors (PRR). Ved hjelp av dem kan cellene detektere endringer i glykosyleringsmønsteret på kreftcellers overflate og molekylære mønstre i patogeners cellevegg og genom. C-type-lektiner er en klasse av PRR-reseptorer som hovedsakelig kan detektere karbohydrater. For mange av disse reseptorene er det ukjent hvilke molekyler som gjenkjennes og hvordan de bidrar til immunforsvarets respons.

I mitt doktorgradsprosjekt har jeg studert de aktiverende C-type-lektiner kodet av APLEC-genklynge i rotte. Disse lektinreseptorene er dårlig karakterisert i mennesker og andre dyr.

$\mathrm{Vi}$ viste at to av disse reseptorene, MCL og Mincle, er knyttet sammen i et kompleks. Dette komplekset er mer effektivt når det gjelder gjenkjenning og internalisering av partikler enn hver av reseptorene alene. Dette funnet kan ha viktige implikasjoner for in vivo-funksjonen av Mincle, som nylig er blitt identifisert som en reseptor som gjenkjenner molekyler på overflaten av

I tillegg har vi studert ekspresjon av MCL, Mincle og DCAR i rotteorganer og påvist uttrykk i blodmonocytter, granulocytter, eosinofiler og makrofager i lunge, milt og bukhule. Dette reflekterer immunovervåkingsfunksjonen til disse cellene. Makrofager $i$ lever og tarm viser derimot nedregulert uttrykk.

\section{Ana Lobato Pascual}

alobatopascual@gmail.com Mycobacterium tuberculosis.

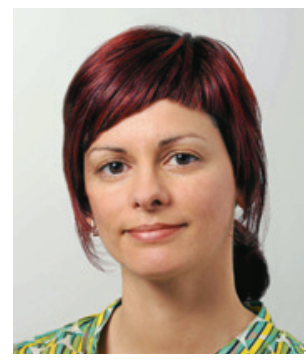

Ana Lobato Pascual. Foto: Gunnar Fredrik Lothe, Institutt for medisinske basalfag

Disputas

Ana Lobato Pascual disputerte for ph.d.-graden ved Universitetet i Oslo 6.2. 2014. Tittelen på avhandlingen er Molecular characterisation of activating receptors in the rat APLEC gene complex.

\title{
Farmakoterapi hos voksne med AD/HD
}

\section{En stor andel av voksne med AD/HD fungerer dårlig i skole og arbeidsliv. Etter langtidsbehandling med medisiner var det bedring av symptomer og funksjonsmål.}

Et stigende antall voksne med attention deficit/hyperactivity disorder (AD/HD) har søkt helsehjelp det siste tiåret. Det har aktualisert spørsmål om nytten av lengre tids farmakologisk behandling av tilstanden.

I mitt doktorarbeid gjennomgikk jeg forskningslitteratur omkring langtids farmakoterapi ved $\mathrm{AD} / \mathrm{HD}$ hos voksne og ledet en prospektiv åpen studie av tidligere umedisinerte voksne $\mathrm{AD} / \mathrm{HD}$-pasienter som fikk medisiner etter nasjonale retningslinjer.

Ved litteratursøk fant vi noen få kontrollerte legemiddelstudier, av varighet fra 24 uker til ett år, og noen åpne studier av lengre varighet, men med stort pasientfrafall. Resultatene indikerte vedvarende effekter av medisiner.

I den kliniske studien $(\mathrm{n}=250)$ hadde en stor andel av deltakerne (56\%) ikke fullført videregående skole, og mange (51 \%) var arbeidsuføre ett år eller lenger. Mange hyperaktivitets-impulsivitets-symptomer var assosiert med manglende utdanning, mens oppmerksomhetssvikt var mer knyttet til langtids arbeidsuførhet. Ved ettårsoppfølgingen $(\mathrm{n}=232)$ foretrakk et flertall $(70 \%)$ å fortsette behandlingen med AD/HD-medisin. Av disse viste $87 \%$ god bedring. I en longitudinell analyse fant vi dose-responssammenheng. Ingen alvorlige hendelser ble observert.

$\mathrm{AD} / \mathrm{HD}$ hos voksne er relatert til store vansker i utdanning og arbeid. Medikamentell behandling under nøye oppfølging kan anbefales som nyttig og tolereres av mange pasienter, men det er behov for flere og prospektive studier over lengre tid.

Mats Fredriksen

mats.fredriksen@siv.no

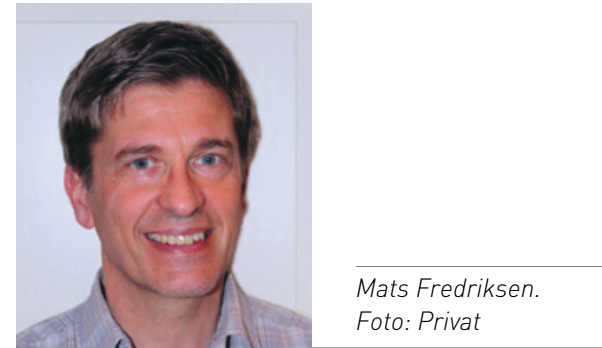

Disputas

Mats Fredriksen disputerte for ph.d.-graden ved Universitetet i Oslo 18.6. 2014. Tittelen på avhandlingen er Long-term pharmacotherapy of adults with Attention-Deficit/Hyperactivity Disorder (ADHD): a literature review and clinical study. 